UC-NRLF

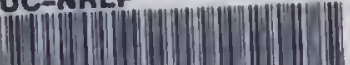

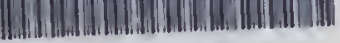

B $2888 \quad 053$ 


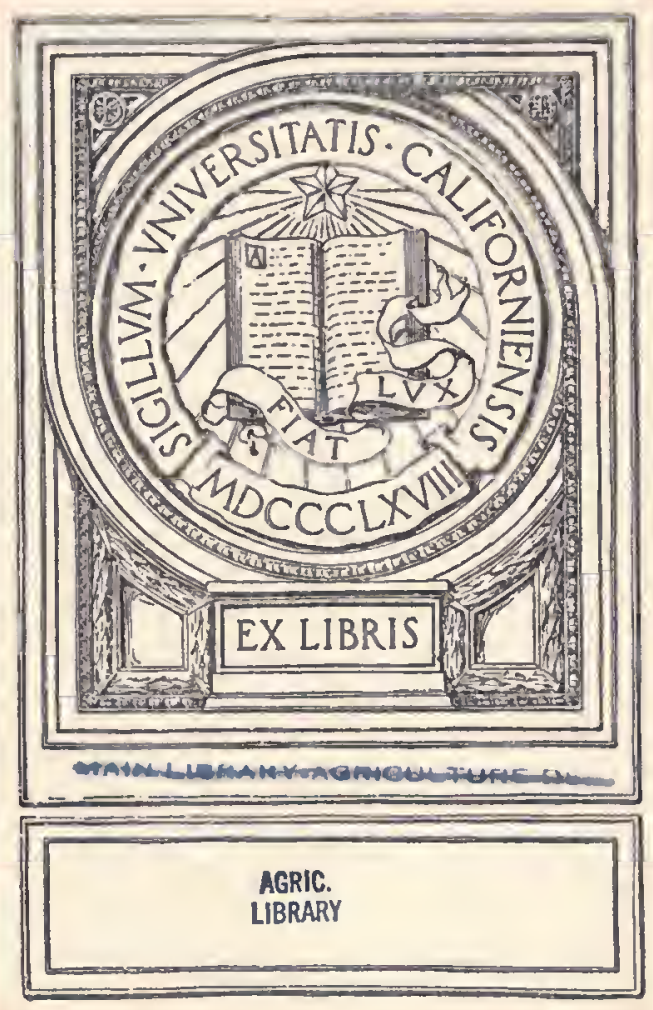



Digitized by the Internet Archive in 2007 with funding from Microsoft Corporation 
MINISTRY OF AGRICULTURE, EGYPT.

Technical and Scientific Service. Bulletin No. 26. (Entomological Section.)

\section{THE OUTBREAK OF}

\section{PSEUDOCOCCUS SACCHARI, CKIII.,}

\section{ON THE SUGAR CANE OF EGYPT.}

By W. J. HALL, A.R.C.S., F.L.S.,

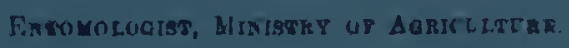

(Editod by the Publicatlon Committes ol the Alinistry of Agriculute which is not, as a budy, responsible fer lle oplulows expressed fir this Bultorin.) May 10, 1922.

Government Press, Cairo, 1922.

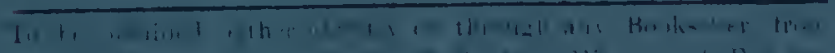

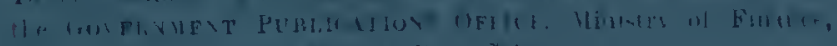
Price - - - - P.T. 3. 



\section{MINISTRY OF AGRICULTURE, EGYPT.}

\section{Technical and Scientific Service.}

Bulletin No. 26. (Entomological Section.)

\section{THE OUTBREAK OF}

\section{PSEUDOCOCCUS SACCHARI, Ckll.,}

\section{ON THE SUGAR CANE OF EGYPT.}

By W. J. HALL, A.R.C.S., F.E.S.,

Fintomolonist, Ministri of Aariodlture.

(Edited by the Pubilication Commitice of the Ministry of Agriculture which is not, as a body, responslble for the opinions expressed in this Bulletin.)

[May 10, 1922.

- Government Press, Cairo, 1922.

To be obtained, either directly or thrungh any Bookseller, from the covianment Puhitations OfFicr, Ministry of Hinance, Dawarin P.O., Cairo.

Price - - - - - P.T. 3. 



\section{Government Press}

4912-1922-150 ex.

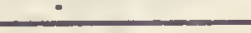




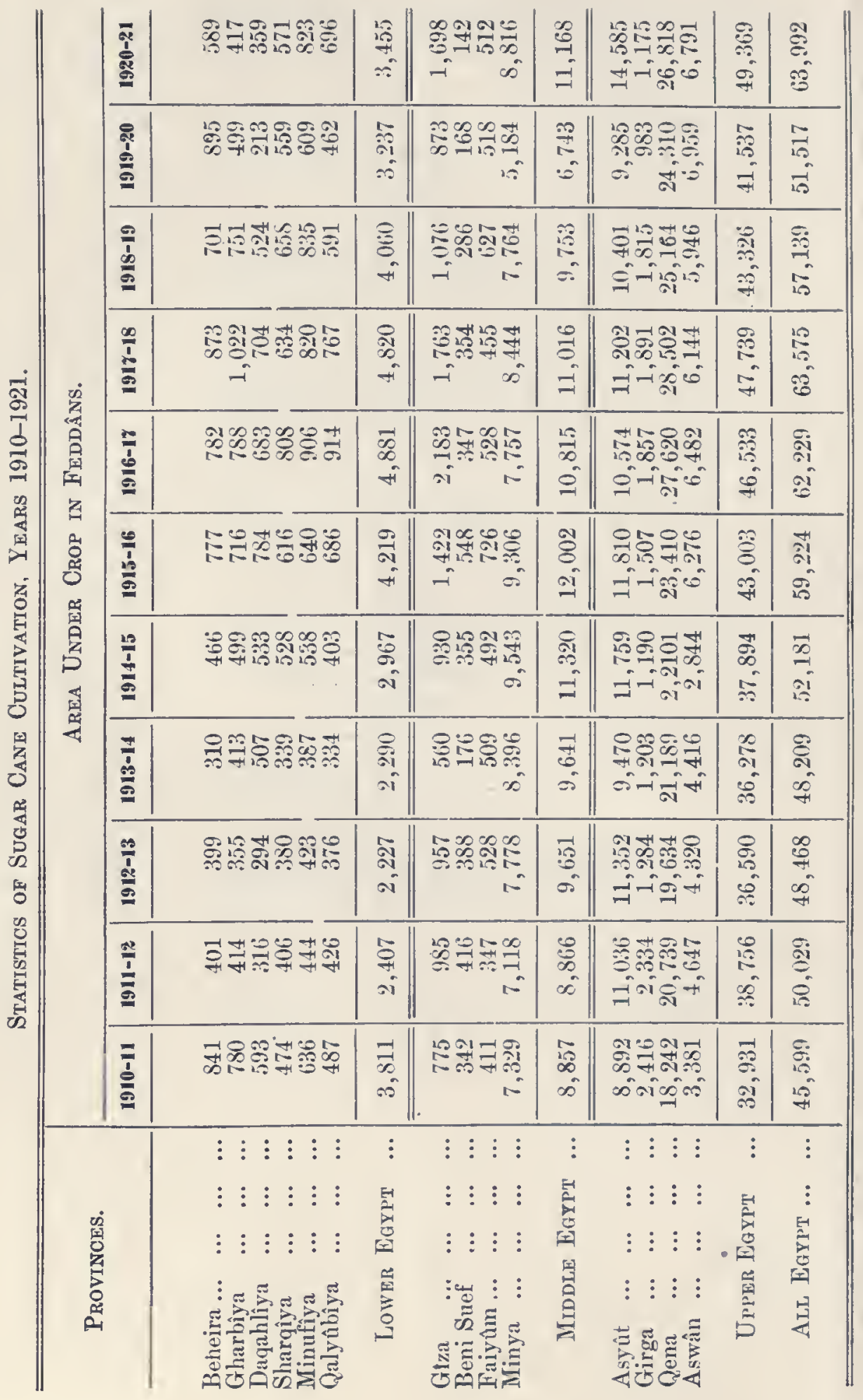




\section{MINISTRY OF AGRICULTURE, EGYPT.}

Bulletin No. 26.

\section{THE OUTBREAK OF PSEUDOCOCCUS SACCHARI, Ckll., ON THE SUGAR CANE OF EGYPT.}

The sugar cane cultivation of Egypt dates back to 1848, in which year Ibrahim Pasha introduced a red variety from Jamaica: the variety now known as "Baladi." The experiment met with such success that a factory was built at Roda in 1855 to extract the sugar from the cane, and so profitable did it prove that the area under sugar cane increased yearly. Sugar cane is now one of the major crops of Egypt and the old Roda factory has long since been replaced by six or seven others of more modern type situated at intervals throughout Upper Egypt. The sugar production of Egypt at the present time is practically a monopoly of the Société Générale des Sucreries et Raffinerie d'Egypte and all the factories with one exception belong to thein.

In 1903, owing to the low market price of sugar, the low production of "Baladi" cane, and the ligh prices obtained by other crops, it was realized that unless a higher producing cane was found the future of sugar prodıction in Egypt was doomed. Accordingly M. Henri Naus Bey of the Sugar Company visited Java, Borneo, Hawaii, etc., and brought back 128 selected varieties of sugar cane. Amongst these was found a variety called "Java 105 " which possessed the necessary characteristics for revitalizing the industry.

It might be as well here to compare "Baladi" and "105," the two varieties almost exclusively grown in Egypt to-day.

Although " 105 " cane contains a slightly lower sugar percentage -12.5 to 13 as against 13.5 to 14 - and a slightly lower degree of purity, it has the characteristic of giving a much higher yield of cane per feddân than the "Baladi." In the first year it produces about 200 quntârs per feddân* more cane and whereas in the second year the yield per feddân only falls off by 100-150 qantârs, in the case of "Baladi"

- 1 ‘antîr $=41 \cdot 928$ kilos. $=95 \cdot 0 . j \mathrm{lbs.}$

1 feddân $=4,200 \cdot 833$ square metres $=5,024 \cdot 17$ square yards $=1 \cdot 038$ acres. 
it falls off from 150-200 qantârs, so that over a period of two years a field will produce 400 qantârs per feddân more cane or an increased yield of over 30 per cent. On well cultivated good land " 105 " will give in the neighbourhood of 900 qantârs, and it has an additional advantage in that it will produce a remunerative crop on poor land.

This increase in production of the " 105 " variety over the "Baladi" is due to the fact that the former grows much nore slowly than the latter in the early stages and some of the lower eyes grow out giving a greater number of canes per set planted. On the other haud "Baladi" cane is stonter and finer in appearance.

The " 105 " cane, however, possesses one serious drawback, once the cane is cut inversion of the sugars rapidly sets in. Consequently it has to be passed to the factory after cutting with the utmost despatch, a delay of more than twenty-four hours being sufficient to. reduce the available crystallizable sugar content.

Sugar cane is grown in Egypt for three purposes:-

(1) Human consumption (chewing).

(2) "Honey" manufactured in the villages for local consumption.

(3) Sugar production.

By far the most important of these is the sugar prodnction and it is chiefly with sugar cane grown for this purpose that the present paper deals.

The attached table shows the areas under sugar cane cultivation for the last ten years, and it will be seen that the Provinces of Minya, Asyût, Qena, and Aswân claim by far the greatest areas. 'These are the provinces served by the factories of the Sugar Company; the other provinces, with the exception of Girga, only produce cane for human consumption (chewing).

The chief localities under sugar cane in the various provinces and the factories by which they are served are as follows:-

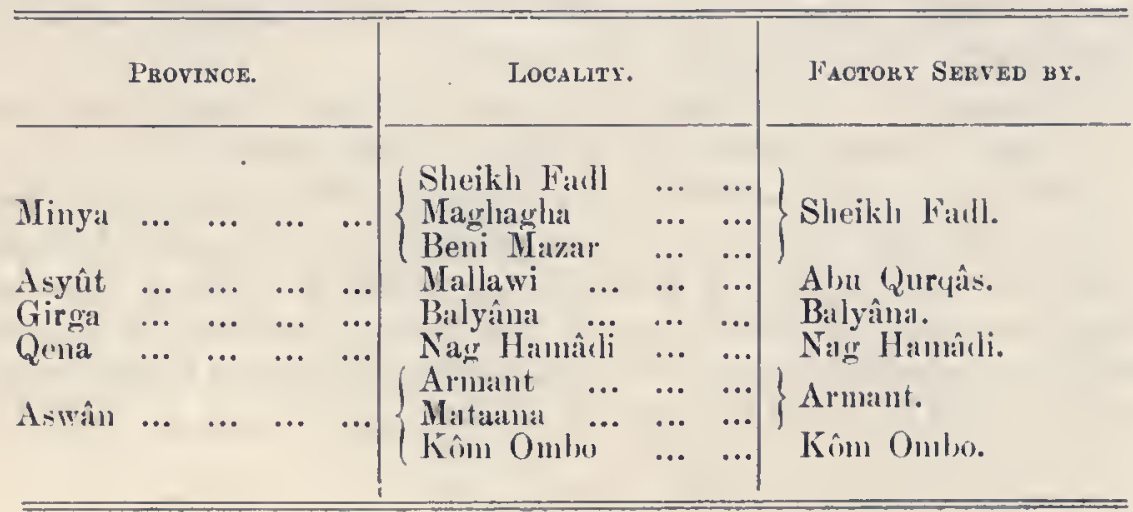


The only factory not belonging to the Sugar Company is a small one at Balyâna. 'This belongs to a certain family of big land-owners at Balyâna who supply it with sugar cane of their cultivation.

Reference to the table will show that the total average acreage muder cultivation is in the neighbourhood of 57,000 feddâns producing about 40,000,000 qantâr's of cane yearly. 'The average yield per feddân is about 650 qantâr's, but that depends on the variety of cane grown, and as our statisties of the average yield per feddân are compiled irrespective of the variety and the percentage of first, second, and third year growth, they are misleading for the purposes of the present paper and have been omitted.

'The Sugar Company absorb more than two-thirds of the total crop, although with the exception of a few thousand feddâns at Nag Hamâdi they cultivate practically mo land themselves. The cane is

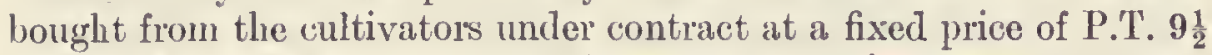
per qantîr for 1921-1922 and P.'T. 6 for the coming season of 19221923.

It is not so much the cultivation of sugar cane as the manufacture of sugar from the cane that has received such a severe set-back from the ravages of the Sugar Cane Mealy Bug - Pseudococcus sacchari CKLL.indeed such a setback that the whole future of the industry hangs in the balance.

Pseudococcus sacchari CKLL. is a nealy-bug of world wide distribution and was known in Egypt as far back as 1912. It was not, however, until the end of the war that it came into prominence, and from 1918 to the present time it has increased to such an extent that the whole sugar cane crop of Egypt is infected to a greater or lesser degree. Unforturately by far the worst attack is at Nag Hamâdi, the biggest area under sugar cane cultivation. 'The other areas are already bad, and they will become considerably worse if measures are not taken to arrest the outbreak. Kôm Ombo is probably the most lightly attacked, but the cane there suffers from lack of land drainage which gives rise to very irregular growth.

'The two main reasons for the outbreak are:-

(1) Bad cultivation during the war.

(2) 'The introduction of the " 105 " Java cane.

(1) Prior to 1914 the fuel used in the sugar factories was coal, but during the war the price rose to such heights that its use became economically unsound. Consequently it was replaced by trash, i.e. the leaves and refuse from the fields. This trash, which contains millions of living insects, is conveyed loose either by trucks or other means of trausport from all parts of the sugar growing area to the factories. Some of this is unavoidably dropped or blown off and the 
whole track becomes strewn with leaves from which the inseets crawl on to the adjacent standing eane, thereby steadily distributing and inereasing the infection. There is at leastfour months between the time the first eonsignment of trasl is eonveyed to the factory and the last field harvested, so that insects from the first eonsignment may have up to four months in which to inerease the infeetion on already infected eane.

Further, as the price of sugar rose during the war, the area under cultivation inereased and the cultivation beeame worse and worse: poor quality " sets" were planted and no trouble was taken to remove the leaf sheaths from the "sets" before planting. Cane was ratooned four and five times and eane followed cane on the same land year after year. No attempt was made to clean up the fields after the liarvest until quite recently, and this bad cultivation during the war together with the removal of trash from the fields has undoubtedly been largely responsible for the outbreak.

(2) In comparing "Baladi" and " 105 " cane one charaeteristic was omitted; the leaf sheaths of the former are not so closely adherent to the parent cane as in the latter and the lower sheaths tend to eome away from the parent cane and break off elean at the node. The inscet therefore cannot get the same shelter as is afforded by the closely adhering leaf sheatlis of the " 105 " and consequently does not find the "Baladi" eane quite such a congenial breeding ground. For this reason the former variety does not become so heavily infected as the latter.

It has already been pointed out that " 105 " cane was first introdueed in 1903, but it was not until 1909 that the Sugar Company authorized the cultivators to plant out " 105 " cane. Permission was first granted to introduce 25 per cent and this was later increased to a maximum of 50 per cent. In spite of this limit the cultivators developed the variety to such an extent that, in 1915,95 per cent of the cane passed to the factories was "105." This gradual replaeement of the "Baladi" variety by the " 105 ," whilst admittedly essential to save the industry, has undoubtedly favoured the increase of Pseudococcus sacchari CKLL.

The cultivation of "Baladi" cane for human consumption still continucs owing to its slightly higher sugar eontent, and the fact that it is a finer cane. About 500 feddâns per province are cultivated for this purpose and the price obtained for the first year crop is sueh as to more than counterbalance the lowered yield of the second year.

\section{Description and Habits of the InseCt.}

The adult female is large, elongated, ovate, decidedly plump, and delieate pink in eolour; it is only very sparsely mealy and the 
segmentation of the adbomen is apparent. Marginal filaments are wanting. It is ovo-viviparous and gives rise to a little very loose white fibrous secretionary matter and much "lioney dew." The female is only active normally in its young stages, but it retains the power of locomotion throughout life.

Length of adult female 6 to 10 millimetres. Breadth 3 to 5 millimetres. The male does occur in small numbers, but is not of any economic importance and may be disregarded.

The adult female produces living young partlienogenetically, i.e. without the intervention of the male. The fact that there is no ovisac or external eggstage is one of considerable importance in connection with the control of the pest.

The position favoured by the insects on the cane is that immediately below the node where they are sheltered by the close adherence of the leaf sheath arising from the node below. Any tendency towards movement is always directed to a higher node where more tender growth is to be found; the young females shortly after birtl migrate to the next node or to some higher node where they settle down to feed and normally complete their life-cycle without a further change of position. Migration to the most tender growth near the growing point is prohibited by the extremely close adherence of the leaf sheaths beneath which the insects are unable to penetrate and find shelter. The only insects ever found at a place othe: than immediately below the node are those young females migrating to a more congenial fecding place in which to complete their life-cycle.

\section{Nature of Damage.}

The insects feed by inserting a long sucking tube into the hostplant and withdrawing the plant juices. The result of thousands of these insects at work is the production of gum on the outer surface of the cane. This sticky secretion is formed partly by the exudations (honey dew) which are invariably associated with large colonies of any mealy bug and partly by the exudations from the cane, a defensive measure induced by the wounds caused by the insertion of the long sucking tilbes. This gummy mixture tends to move downwards so that in heavily infected canes all the internodal surface of the cane becomes coated and it collects just above the node where it is held in place by the leaf sheath arising from that node. I may point out here that this gumming makes it very difficult to strip the canes of their leaf sheaths and, as the " 105 " variety is normally more difficult to strip than the "Baladi," cultivators are obliged to employ more labour for this operation. 
I have been struck by the fact that the amount of gum varied in different fields in spite of a similar intensity of attack. I think we may assume that the "honey dew" produced by any given number of healthy insects under similar conditions is approximately the same and the variation must therefore be due to variations in the quantity of the exudations from the cane. It seemed that the healthiest and finest canes produced the most gum, and it may be that as the exudation from the cane, is a defensive weapon, a healthy cane is better equipped for the fight and consequently produces more gum. On the other hand it may be due to variations in the cane induced by chemical differences of the soil on which the cane is grown. This requires further investigation. The relation of sap flow and irrigation to gumming is another line of research that would give interesting results.

Not only does the insect impair the health of the cane but indirectly through the production of gum it has very far reaching results upon the available sugar content. It is found that when infected canes are crushed and passed through the factory, the crystallizable sugar content is much reduced. How far this is actually due to the presence of the gum and how far to subtle changes induced within the cane I am not in a position to state. A very simple experiment proved that the "honey dew" reduced and even inlibited crystallization, and in any case the reduction in sugar output is traceable to the ravages of the insect.

The gravity of the situation from a commercial standpoint is obvious. All the cane passed through the factories is gummy to a greater or lesser degree and not only is such cane far more difficult to work, but the percentage of crystallizable sugar obtained is so reduced as to entail a loss to the Sugar Company of hundreds of thousands of pounds.

\section{Suggested Control Measures.}

The nature of sugar cane is such that it is impossible to carry out any prophylactic measures whilst the cane is growing in the field. It might be possible to remove the gum from the canes, assuming that the gum alone is responsible for the reduced sugar output, but this would be by no means easy and when one realizes that the factory at Nag Hamâdi deals with over a million canes daily it is difficult to see how it could be carried out practically. It is much more sound to deal with the cause than to pay attention to the effect of the attack, and the most effective lines of control are those directed to the "sets" planted and to the methods of cultivation. 
I will proceed now to discuss in detail the various control measures suggested.

\section{Clean "Sets" must be planted.}

The method of planting usually adopted in this conntry is to plant lengths of cane abont 18 inches ( 46 centimetres) long in pairs, the pairs lying end to end and abont 6 inches ( 15 centimetres) below the level of the ground. At the present time it is practically impossible to obtain cane for planting that does not carry living insects, and every field planted is infected from the very start. If it is possible, however, to so treat the "sets" before planting that all the insects are killed without impairing germination then that cane will grow up free from disease and any infection which appears subsequently will have been derived from external sources.

A series of experiments was carried out to find a solution for the treatment of the "sets" which wonld not be too costly and yet meet the requirements. A number of different liqnids were tried and in each case the "sets" were completely immersed.

(a) Hot water at a temperatmre of $60^{\circ} \mathrm{C}$. only killed 10 per cent of the insects and it failed to dissolve the wax or fibroid material.

(b) Cyllin. Solutions of 3,5 , and 10 per cent were tried and the mortality in each case was about 60 per cent. The wax appeared to be partially dissolved, but the fibroid material was untouched. Cyllin made up with hot water was also not fully effective.

(c) Lysol. 3, 5, and 10 per cent gave the same results as in the case of Cyllin.

(d) Clensel gave the same results as Lysol and Cyllin.

(e) Carbon Bisulphide. This was very effective. Inmersions for twenty seconds lilled every insect, but it is unsatisfactory owing to the fact that it is expensive and extremely inflammable. It would be dangerous to handle in large quantities.

(f) Paraffin emulsion. This gave excellent results. The stock solution was tried at various dilutions and it was found that a dilution of one in thirty killed every insect if the set was immersed for two minutes. This solution dissolves the wax, has a good wetting power, and kills 100 per cent of the insects.

The proportions of the ingredients in the stock solution are as follows :-

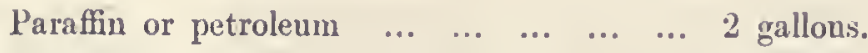

$$
\begin{aligned}
& \begin{array}{lllllllllll}
\text { Water... } & \ldots & \ldots & \ldots & \ldots & \ldots & \ldots & \ldots & \ldots & 1 \text { gallon. }
\end{array} \\
& \begin{array}{llllllllll}
\text { Sunlight soap } & \ldots & \ldots & \ldots & \ldots & \ldots & \ldots & \ldots & 1 & \mathrm{lb} .
\end{array}
\end{aligned}
$$


'- The soap in this solution is double the amount nsed in the normal solution in order to inerease the wetting power.

"Sets" immersed take up a darkish green hue and when on tmergence they cease to have this hue it is time the solntion should be reinforeed. The solution will last for an hour to an hour and a half if it is eonstantly in use without the addition of further stoek solution. At the present price of paraffin the eost of treatment eomes to about P.T. 100 per feddân, inelıding the eost of extra labour. 'This is rather expensive, but as the value of a feddân of sugar eane varies from L.E. 60 to L.E. 80 , it is not more than an insuranee of $1 \frac{1}{2}$ per eent and the cultivators would get this baek, and eonsiderably more, in the inereased yield per feddân.

The chief objeetion to the use of paraffin emulsion is the difficulty of preparing it ; unless it is eorreetly made up it is useless. Snggestions for surmonnting this diffieulty will be found on a later page. It is hoped that another solution may be found which will remove this obstacle, but for the present no sueeess has been met with.

It is important to remember that immersion is of no avail unless the " sets" are eompletely stripped of all leaf sheaths. 'The insects lie hidden beneath the leaf sheaths and no solution will penetrate there and kill the inseets. The leaf sheaths, then, must all be removed, and this process must be not earried out on the field to be planted out. The stripping should be done in the field of origin of the cane and the "sets" brought to the field of planting, dipped, and sown. It is needless to point out the danger of stripping the canes of their infected leaf sheaths on the field about to be planted.

I cannot lay too much stress on the importanee of the planting of clean "sets." Once we start with clean cane in our fields it should not be so diffieult to keep it elean and the remaining suggestions are subsidiary and designed for this purpose. The crux of the whole problem, however, lies in the sowing of clean ". sets."

\section{Cane Should only be Grown for two Years on any Field untL the Pest is UNDer Control.}

The expense of eultivation makes it a great temptation for the eultivator to leave his eane in and ratoon three or four times, the limiting factor being the reduced yield. In Barbadoes sugar eane is a one-year crop and in the West Indies generally ratooning does not usually take place more than once or twice. It is true there are other reasons for this, but with the severity of our present outbreak it is high time that ratooning should be limited to once and certainly never more than twice. The yield steadily deteriorates as the years proceed and the insect attaek steadily increases. How far the reduction in yield is direetly attributable to the insect attack it is 
difficult to say, but there is no doubt that the insect is largely responsible for it. Until such time as the pest is under control it will be wise only to grow eane on any one field for two years. It may be pointed out that the yield per feddân of third, fourth, and fifth year cane is such that it is hardly profitable and making cane a two-year crop would not be any great hardship to the cultivator.

\section{3. 'I'He "Trash" not to be usen in the Factories as livel.}

Attention has already been drawn to this. I would suggest that if it is essential for the Company to use "trash " as a fuel that, instead of transporting it loose, it might be eompressed into bales. Portable presses can be bought at a low figure and readily used in the fields. This method would have the additional advantage that a far greater weight of "trash" per truek could be transported. I do not advise this method, but it would be preferable to the existing practice. Now that the price of coal has fallen practically to pre-war rates I see no reason why the use of coal should not be resmmed.

Another alternative is to grow Sessaban (Sesbania agyptiacu) around the fields. Sessaban has quite a high calorific value, grows moderately rapidly and requires no attention. At Armant it is grown for use in the factory, and this is a practice that might well be adopted more generally.

\section{The IAND SHOULD BE THOROUghLY CLEANED IMMEDIATELY AFTER THE HARVEST.}

'The present system is to remove the great majority of the " trash" to the factories and villages and then to burn over the land. No "trash" should be removed from the field; the whole should be thoroughly burnt. This would account for a very high percentage of the insect population and would remove one of the most favourable methods of distribution.

\section{Cane should not be grown on Cane.}

During the war cane was frequently grown after cane on the same land, and although it is not now so prevalent I have met with many cases. Apart from any agricultural considerations it is a practice which militates against the control of the pest by carrying on the infection. It would be of very little value to plant clean "sets" on land from which cane had only recently been removed, there would always be sufficient infection, however, well the land had been cleaned, to reinfeet the new crop. 
An experiment was earried out at Nag Hamâdi last winter on a large scale by the Sugar Company in which "sets" treated in emulsions of inazoot and paraffin of varying dilutions and for varying times were planted out. The field chosen was planted out at the beginning of October and was land which had horne cane for the previous three years, the last crop having been harvested the previons April. This land was not properly worked over until shortly before planting, thus providing the insects sufficient food to carry on until the new "sets" were planted. When I examined the field early in Deeember 75 per cent of the young shoots were infeeted. In two small plots the "sets" had been dipped in pure paraffin and mazoot respectively, only one per cent of these had germinated; but even they were found to carry living inseets. This is eonclusive proof that the insects lad reinfected the canes subsequent to planting. It was unfortunate that sueh a field should have been seleeted for so elaborate an experiment as any results obtained are not only valueless but actually misleading. I may add that I also found in many cases that the "sets" had not been thoroughly stripped of leaf sheaths, thereby affording the insects shelter during immersion.

The planting of cane in Oetober is unusual and should be liscouraged from the outset. Cane thus planted is cut in January or Feloruary year, i.e. after a growing period of sixteen months. This is bad for insect control, affording as it does a longer period for the insect in which to breed and work its ravages. Also it does not appear very economical as the land is occupied for the better part of two years to give only one eutting. The normal time for planting out is from March to May and for cutting from December to Mareh.

After the land, then, has been under eane for two years (one ratooning) it should be given a rest for at least one year and may during this time be planted out with any other crop at the discretion of the owner, This enables the land to free itself of all infection before the next erop is planted.

I have not yet found Pseudococcus sacchari CKLL. on any other crop or weeds around the field. Halfa grass, whieh is prevalent everywhere, does not appear to be infected; it would be a very serious stumbling block to the control had it proved susceptible. The only other host plant I have yet found is that known as "Heesh": Saccharum biflonum or ogyptiacum. This plant, which grows along eertain canals and on waste spaces, is thought to be the original aneestor of our present cultivated sugar cane, so it is not altogether unexpeeted that Pseudococcus sacchari CKLL. should bestow its attentions upon it. Fortunately "Heesh" is not frequently found in the neighbourhood of the sugar cane fields and so the attack on this grass need hardly be considered in connection with the control of the outbreak on the sugar cane. 
6. As far as possible Big Areas should be planted with Cane and there should not be Smalt Areas of Cane of Difreren't YeARS INTERMIXED WITH OTHER CROPS.

Second year cane is naturally more heavily infected than first year cane and the risk of infecting first year cane where the "sets" have been treated is great if that cane is in close proximity to infeeted second year cane.

First, seeond, and possibly third year cane in close proximity means that there is an endless chain of infection which it is very difficult to combat by any control measures and thus it would be advisable as far as possible to grow cane in big areas. Every third year the land would then be oceupied by some other crop and a break in the sequence of host plants for the inseet effected.

Summarizing the foregoing control measures 1 would suggest that:-

(1) Clean "sets" be planted.

(2) Cane should only be grown for two years on any field until the pest is under control.

(3) 'The "trash" should not be removed from the fields or used by the factories as fuel.

(4) The land should be thoroughly cleaned inmediately after the harvest.

(5) Cane should not be grown on eane.

(6) As far as possible big areas should be planted with cane.

I should have liked also to suggest that the growth of "Baladi" cane be encouraged, but that is hardly practieal. The cultivator conld not be expected to comply with this owing to its low yield; it would not be worth his while to cultivate "Baladi" eane at the eurrent price per qantâr offered by the Sugar. Company. This, however, is not at all essential if the suggestions put forward for the control of the outbreak are adopted.

\section{Suggested Method of Application of the Control Measures.}

Larly this year an attempt was made to induce cultivators to exereise control measures by propaganda, and they were circularized with a pamphlet pointing ont the dangers to the erop and the steps to take. 'The Government further undertook to supply any cultivator with the neessary paraffin emulsion at cost price. This campaign did not prove a sueeess. 
In dealing with a problem of this nature the control measures must be universally adopted to meet with full success, otherwise the cultivator who carries them out is penalized by his neighbour who does not. I estimate that, if the recommendations were adopted generally, the pest would be well under control in three or at the outside four years and that certain of the measures could then be relaxed.

It is not easy to devise a satisfactory practical method for the application of these control measures, and it is impossible unless the Sugar Company co-operates with the Government. The Sugar Company has everything to gain by such co-operation; the cultivator, on the other hand, will not be quite so easily convinced at first, owing to the fact that it costs a little and sugar cane is not such a very profitable crop to him. After the first year, when he realizes that he recovers more than his outlay in the increased yield per feddân, it will be easy.

The chief difficulty is how the cultivator is to obtain clean " sets." No cultivator, with the best intentions in the world could do this for himself without assistance, and I suggest that it should be made possible for him to obtain guaranteed clean "sets" at cost price. The Sugar Company could provide these by growing the necessary cane on their own land and, treating and distributing them from their factories against demand. Indeed I would go further. I suggest that the reduced price paid for the cane by the Company is placing the onus of this outbreak on the cultivators. The cultivator is not altogether responsible for the outbreak and with the low price prevailing it is doubtful if much new cane will be planted, and it will be extremely difficult to convince him of the advisability of paying for the control measures. Therefore I suggest that the Sugar Company might either provide the clean " sets" free of charge or increase the price paid for clean cane. One cannot expect the cultivator to bear the brunt of both the outbreak and the control measures. It would pay the Company a hundredfold to provide clean " sets" free of charge to cultivators; P.T. 6 per qantâr is an extremely low figure for the clean cane which they would get back in return and the profit that would accrue on that score would more than counterbalance the expenditure in the provision of clean "sets."

The actual execution of this proposal would not, I think, present any serious difficulties to the Company, and the Government might, I suggest, step in and by law decree that no " sets" other than those bought or obtained from, and certified clean by, the Sugar Company might be planted in the big sugar cane growing areas.

'The objection may be raised that not all the cane grown in the big areas finds its way to the factories. That is correct, but it would not cost the Company anything beyond a little extra trouble to provide 
"sets" for all and the control of the pest is at stake which means everything to them. "Scts" issued to cultivators not supplying the Company would, of course, have to be paid for.

Another point that may suggest itself is that the planting of any field is dependent on the arrival of the water supply, and the cultivator cannot tell until a few days before when he will plant out. Conscquently it may occur that prepared "sets" are hcld up for a week or two before planting. The inversion of the sugars which takes place so rapidly in the "105" cane does not affect the germinating capacity; the "sets" will survive for considerably longer than two wceks, so that a slight delay in planting out need be no cause for alarm.

Assuming, then, that the Sugar Company provided clean "sets" and the Government laid down by law that only such "sets" were to be planted, the main control measure would be enforced. The other measures, with the exception of No. 6, could also be included in the law and their cxccution would not prove any hardship to the cultivator except in so far as he would be deprived of the "trasli" for fuel.

Recommendation No. 6 would not be casy to enforce, but it might be effected by the judicial arrangement of the contracts entercd into by the Company with the cultivators. It would take at lcast two years to carry out without imposing too great restrictions on the cultivator and would need very careful working out.

\section{Natural Enemies.}

Only two natural enemies have been found to be of any assistance in the control: the rat and a fungus.

(1) In every area inspected last winter I noticed that on heavily infected canes a part of the leaf sheath immediately below the nodc would be torn away and the parent cane revealed. These "windows," so to speak, were always in exactly the samc place, just below the nodc, and no insects were ever found on the surface of the cane thus cxposed although obviously insects had been present. Many such "windows" were found on a heavily infected cane, sometimes as many as nine or ten.

Whatever makes these windows must be feeding on the insects because :-

(a) Canes not infected have no such "windows."

(b) The "windows" are always in the same relative position on the canc, i.e. immediately below the node where the insects invariably congregate. If the animal wanted the gum it would makc the windows immediately above the node. 
(c) ${ }^{-}$Canes on which the insects have already been killed by fungus possess only very small peep holes, as if the animal finding the insects dead has gone elsewhere.

(d) Where there is a "window" there are never any insects on the exposed surface of the parent cane, but ' $m$ lifting back the remainder of the leaf sheath the insects are found on either side of the "window." The animal, therefore, can only get at the insects where it has torn away the leaf sheath.

(e) Scratches are found on the surface of the cane such as might be made by the teeth of an animal in removing the insects.

There is very little doubt that the rat is responsible for these windows as rats are abundant in the fields. Indeed it is difficult to sce what else it would be. On one inspection rats were seen high up on the cane, and an examination of the cane showed that the rats had just been disturbed whilst in the act of making the "windows." The stalks of the canes were only found bitten through by rats where they were uninfected or only very slightly infected, and it appears that the rat has a very decided partiality for a diet of this particular insect.

This can never constitute more than a subsidiary control as it does not come into action until the infection is heavy, but it certainly assists in preventing the attack from becoming overwhelming.

(2) There are two distinct fungoid attacks or possibly they may be two stages of the same fungus.

The more prevalent by far is a green fungus. An insect attacked by this appears at first rather more waxy than usual and short filaments bearing sporangia arise from the body of the attacked insect. These sporangia are at first white but rapidly turn yellow green and then grass green. The insect is killed very quickly and becomes a hard dark mass covered with the green fungoid growth. Insects of all sizes were found attacked by this fungus irrespective of whether they were isolated or in large colonies and all stages from onc insect to every insect in a colony being attacked were observed. In some cases at least 50 per cent of the insects on a cane had been killed by this fungus.

The other fungus is white and commences by an opaque white film forming on the mother cane underneath the insect. In a colony this white matter increases, filling up the interstices between the individual members and then growing over them so that they become completely enveloped and present a soapy opaque white mass. All the insects have long since been killed and on breaking up the mass it is found to be green within. This fungus was found to attack colonies rather than individuals.

It appears that the green fungus grows directly on the insect, killing it, whilst the white fungus grows around it and death from suffocation ensues. 
Mr. Briton-Jones, Mycologist to the Ministry of Agriculture, has very kindly examined the green lungus for me, but up to the present he has got no proof of its being definitely parasitic. He states that the fungus in question is Aspergillus flavus and that he found traces of Aspergillus niger associated with it. I have observed this latter fungus in small quantities on the cane myself, but as it does not appear to affect the insect $I$ have disregarded it. Mr. Briton-Jones suggests that the medium for these fungi may the "honey dew" secreted by the insects and that death may be brought about by the blocking of the glands and spiracles. If the "honey dew" were the medium I should expect to find the fungus growing on the gum which contains a high percentage of "honey dew." This, however, is not the case; I have only observed the fungi growing on and immediately around the insects.

Whether the "honey dew" proves to be the medium or not the fact remains that either directly or indirectly the death of an appreciable percentage of the insect population is effected.

This fungoid attack, like the work of the rat, can only be regarded as a subsidiary control because it only comes into action on heavily infected canes. It may assist in preventing the outbreak from getting completely out of hand, but it cannot be relied upon to exercise any effective control of the pest.

Aspergillus flavus is well known in the West Indies and elsewhere as exercising a controlling influence on the activities of Pseudococcus sacchari CKLL.

No other parasites, either animal or fungoid, were observed, with the exception of fly larva of two different species that were found in very small numbers in one field. Unfortunately the attempts to breed these through were unsuccessful, but no doubt a further opportunity will occur later.

Ants were found to be fairly common, searching as usual for the "honey dew" of the mealy bug. Collembola and Phyllodromia treitliana Werner (BLATTIDA) were also observed, but it is improbable that these are of any economic importance in the control of the pest.

Arrangements have been made to import Cryptolomus montrouzieiri Muls. - a CoccineluID-from the South of France. This species of Cry ptolakmus has proved itself elsewhere a predator of Pseudococcus sacchari CKLL. and other species of Pseudococcus and has been imported and bred in many countries for this purpose. It does not necessarily follow, however, that it will thrive in this country and, even if it does, it will take years to establish itself and make its presence felt. It is therefore of paramount importance that at present reliance for the control of this pest should not be placed on natural enemies, but that artificial measures should be introduced without delay. 


\section{Conclusion.}

Sufficient has been said to indicate the extreme gravity of the outbreak to the cultivators of sugar cane in this country and the lines along which it is suggested that the control might be effected.

Finally, I must express my thanks to Mr. Laing, of the Imperial Bureau of Entomology, for very kindly identifying the insect as Pseudococcus sacchari CkLL., and to M. Henri Naus Bey and the managers and staffs of the Sugar Company for their unfailing courtesy and kindness in affording me every possible facility for the study of the problem.

Cairo, July 1922. 



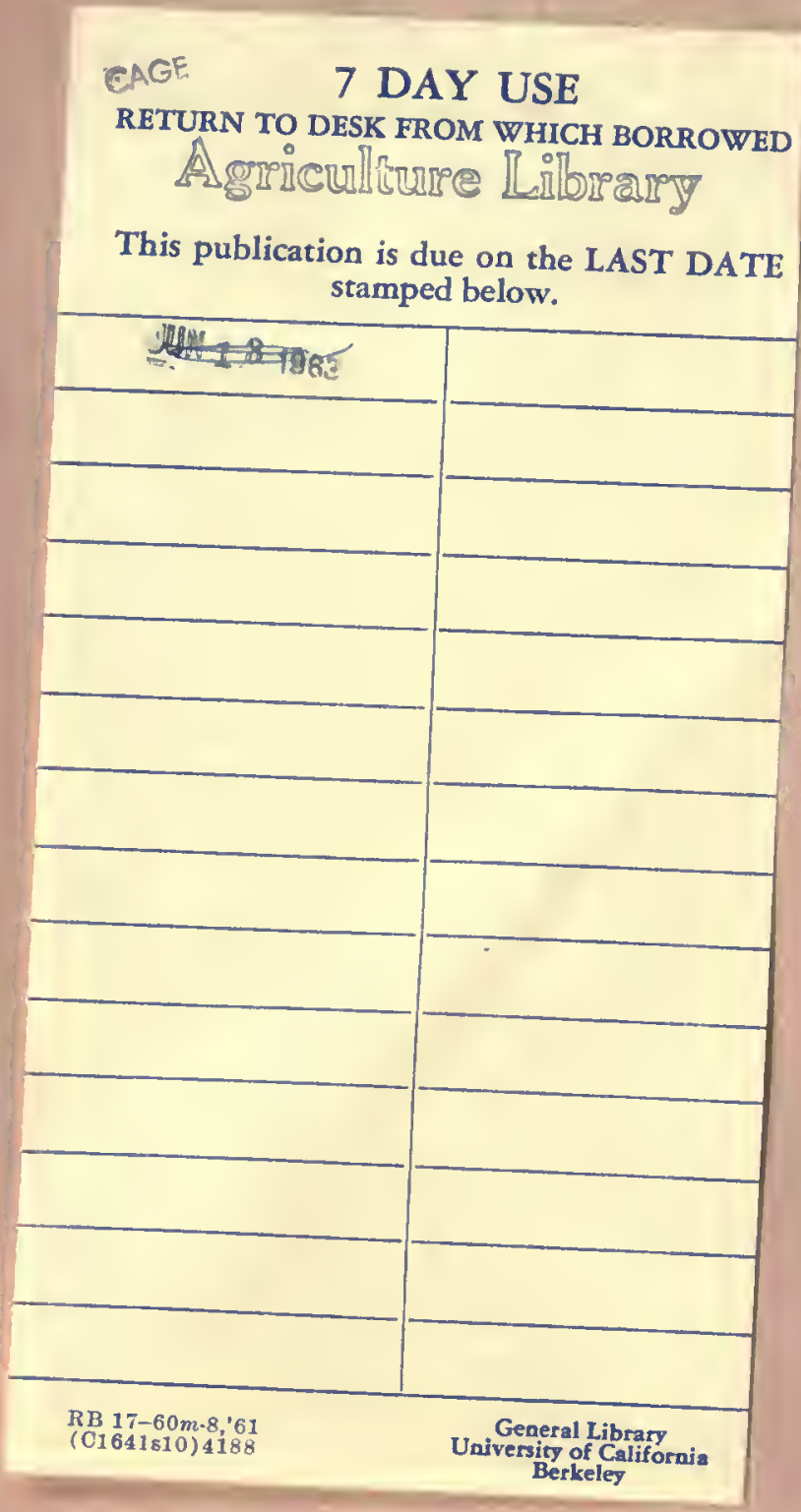


YE 18904 
